\title{
PERSONAL AND COLLECTIVE TRANS-MYTHOLOGIES: CREATIVE ATTITUDES TO GENDER INCONGRUENCE AMONG TRANSGENDER INDIVIDUALS
}

\author{
Anna Maria KŁONKOWSKA ${ }^{1, *}$, Stephanie BONVISSUTO \\ ${ }^{1}$ University of Gdańsk, Faculty of Social Sciences, Institute of Philosophy, Sociology and Journalism, \\ ul. Bażyńskiego 4, 80-283 Gdańsk, Poland \\ ${ }^{2}$ Stony Brook University, Department of Women's, Gender and Sexuality Studies Stony Brook, \\ New York 11794-5356, United States
}

Received 27 September 2018; accepted 26 February 2019

\begin{abstract}
Embedded within the biographies of some transgender people are narratives elements more frequently found in culturally-specific legends settings and the interplay of mythological figures. Individuals who specifically identify as transsexuals (unlike other, non-binary or gender-queer transgender people) sometimes report the wish, the dream, and/or the desire to understand or alleviate their experienced gender incongruence in a surprisingly creative way: through some type of magical transformation. Calling upon recently collected interviews, this study examines those narratives and their use of such elements, noting their reliance on binary gender formations. Through philosophical and cultural-anthropological analyses, we suggest that these fields grant powerful and imaginative personal allowances, opportunities and perceptions to transsexual identifying transgender individuals - magical transformations and justified transpositions to alleviate dysphoria, a surrender of personal responsibility to unseen universal forces, and especially an inherent wisdom gifted during transitional liminality - that neither scientific nor academic evaluations of gender transition can. While these creative allowances are fictive, fantastical, and temporary, they nevertheless articulate a need if not an imperative for understanding, expression and ultimately action on behalf of the transitioning individual.
\end{abstract}

Keywords: creative attitude, gender incongruence, magical transformation, rite of passage, transgender individuals, transsexual individuals, "wrong-body" discourse.

\section{Introduction: magical trans-formative transsexual narratives}

How individuals seek to articulate their transgressive gender identities not only informs their biographies but how they understand their present selves. For instance, in the West the "wrong-body" paradigm (Benjamin, 1966) that describes a gender identity at odds with the sex-assignment of an individual's physicality/biology at birth resulting in cognitive, emotional and physical distress (or dysphoria) is commonly referenced to explain the imperatives

${ }^{\star}$ Corresponding author. E-mail: wnsak@univ.gda.pl 
of transsexual identities. The more a transsexual encounters dissonance between their internal sense of gender and their material form, the further increase of stress they relate, until medical and surgical intervention is warranted. As a long-standing explanatory model, the "born-into-the-wrong-body" model has been one of the most pervasive - and, to gain access to various aforementioned medical and surgical remedies, most widely accepted - of transsexual narratives, often adjusted to the expectations of the medical discourse (as described by Meyerowitz, 2004; Spade, 2000, also see Stone, 1991; Hines, 2007). Yet it is not the only way transgender individuals in binary-gendered societies attempt to understand their identities and subsequently express their need to transition (for accounts of alternative identity formations see e.g. Vincent, 2016; Forrest Miller, 2017).

Embedded within the biographies of some transgender people (who perceive their identity through the aforementioned paradigm) are narratives elements more frequently found in culturally-specific legends settings and the interplay of mythological figures. Individuals who specifically identify as transsexuals (unlike other, non-binary or gender-queer transgender people) have reported the wish, the dream, and/or the desire to understand or alleviate their experienced gender incongruence in a surprisingly creative way: through some type of magical transformation. Utilizing components of folklore and mythos, such personal stories describe a comprehension and/or correcting of gender incongruence through the granting of a seemingly enchanted bodily transformation; a revelatory discovery of individuals as gendered changelings in desperate need of transposition, or that through sheer strength of will, desires could act as catalyst to initiate physical alterations to the body.

This work does not contend that individuals who report these elements as part of their childhood or current narratives believe them to be clarifying their conditions but rather that they reflect a search for understanding of a psychological/physical state that until recently had no formal articulation in a binary-gendered essentialist-based society. That these stories can all be located within the "wrong-body" framework still favored by Western psychological discourses and concurrent medical institution creates a series of interrogative queries: how do some transsexual individuals relate their desires to collective folklore elements? What components of these particular stories become a useful - if not critical - enunciation of their needs to remedy their experienced gender incongruence? What insights may be gleaned by these individuals by using such fictive elements to describe their identity formations? By applying theoretical and philosophical considerations of the relationship between mythmaking and culture to a non-exhaustive cross-sectional study of the transgender community in Poland and the United States (US), this study seeks to understand the association between collective mythology and personal identities, thereby productively adding to the constructions of transsexual narratives.

\section{Methodology}

The applied methodology was inspired by grounded theory in its constructionist conceptualization (Charmaz, 2006). Over the course of the study this paper is based upon, 46 extended, in-depth, semi-structured interviews were collected between 2010 and 2016 among transgender individuals in Poland, and a comparative study (38 interviews) referring to some of the 
issues investigated in Poland, was carried out in the US in 2013 and 2016-2017 (a longitudinal approach). The research participants have been recruited through snowball sampling. All of the interviewees have been informed about the scope and purpose of the study. All the interviews were collected, recorded and transcribed personally by one of the authors of this paper (as many of the research participants would not feel comfortable about third party access to the recordings). The Polish interviews were conducted in Polish and chosen citations have been translated into English.

The data was collected for a larger research project concerning the social and personal situations of transgender people, their societal perception, strategies of negotiations of gender (dis)identities, constructions of femininities, masculinities and non-binary identities (for the study details and wider outcomes, see Kłonkowska, 2017). The analysis for this study encompassed those parts of the interviews that concerned research participants' ways of coping with the experienced gender incongruence, and focused on binary-identifying (transsexual) transgender individuals whose attitudes to their gender identity took a different form than adhering to the medical discourse. It was a cross-case analysis that focused on alternatives to the dominant Western model, and creative approaches to the aforementioned personal identity issues.

\section{Personal trans-mythologies}

A direct inspiration for this paper was an observation that in the course of the interviews, several respondents shared their childhood daydreams that detailed stories rich with imagination, creative thinking and an immense belief in those dreams' fulfillment (compare Kłonkowska, 2017, pp. 110-117). These were stories about a hoped-for magical bodily metamorphosis, coherent with the experienced gender.

Some of the interviewees would speak about patiently, passively awaiting the miraculous transformation they dreamed of Marysia, a Polish transwoman, recalls such memories from her early years at the elementary school:

"Just like in this Cinderella story - I would always read this story. And I also thought that somebody would transform me into a princess. That my fairy god mother or an angel would appear, cast a spell on me and I will be a girl. I just had to be nice and pray for it. I believed in it and prayed for it every evening $\langle\ldots\rangle$ that I would awake the next morning as a girl and that nobody would remember my past" (Marysia, Poland). ${ }^{1}$

Similarly to Marysia, those who were raised in religious families, would pray for it, hoping that one day they would simply wake up in their desired gender and that this " $<\ldots$. will be a beginning of the rest of my life" (Michael, US), as Michael, a US transman, reminisces his childhood.

Some respondents would recall a premonition that some mistake had been made by supernatural powers that should (and definitely will) be undone. Katarzyna, a Polish transwoman in her late 20s, remembers such day-dreams from her childhood:

\footnotetext{
${ }_{1}$ All names have been changed. Citations form interviews carried out in Polish have been translated by one of the authors.
} 
"It was present in my childhood fantasies: that you think that something has been mistaken with your family, that there's been a castling [i.e. changeling], that somewhere there is a girl that wants to be a boy - and here is a boy who wants to be a girl. Because a small child is taught that there are angels, soul, that a human being comes from the god instead of just being born. And that there must have been $\langle\ldots\rangle$ that they have swapped the "wrappings"2 and everything. And that it can be undone: that I should be someone else and somewhere else" (Katarzyna, Poland).

Others also implied this belief in reinstating an inherent original order that was fated yet somehow became disordered. These additional sources would add an element of a perseverance testing one would have to undergo to deserve the desired transformation. Gertruda, a transwoman in her early 60s, recalls such beliefs from her childhood:

"I remember such a tale $\langle\ldots\rangle$ about a boy $\langle\ldots\rangle$ well, now I'm not able to recall it with all the details. Anyway, this boy was initially transformed by some fairy into a dog, because $\mathrm{he}^{3}$ wanted to be a girl. And first he had to be a dog so that he would suffer as a dog. So he suffered $\langle\ldots\rangle$ and the fairy transformed him to a girl's form and then everything's OK, a happy ending. That gave me a reason to cry: thinking that this [such a change] was possible. And I had a wish that it could be possible also in my case" (Gertruda, Poland).

Yet, some people - like Mietek, a self-reliant Polish transman - would, even in childhood, rather believe in the strength of their own will to perform the desired magical metamorphosis:

"When I was four or so, I quickly learned to read and write $<\ldots$. . And I had a Soviet 4 book for children about how to become a sparrow from a human $\langle\ldots\rangle$. Anyway, they [the book characters] managed to become those sparrows by the strength of their will or something. So I thought that if I want hard enough something similar may also happen to me" (Mietek, Poland).

And while he was growing up, his daydreams would become more intentional:

"I've always wanted to become an alchemist. And as they would change other metals into gold, or make some potions of eternal youth, and such miracles $\langle\ldots$. . So I thought that I will develop a genius procedure $\langle\ldots\rangle$ that will make me look like a boy. I even had my secret lab journal I would work on $<\ldots$. " (Mietek, Poland).

In these stories, elements emblematic of folk tales and epic stories, as described by folk tales theorists such as Friedrich von der Leyen (1973), Vladimir Propp (2000), J. R. R. Tolkien (2001), Max Lüthi (1973) or Bruno Bettelheim (2010) are visible: extraordinary incidents and characters episodes from the phantasy world; faith in the intervention of extraterrestrial powers; faith in justice, that everyone gets what they deserve, due to an intrinsic order which whatever confusions might have happened - is always regained in the end. Just as some of

\footnotetext{
${ }^{2}$ Description of ones' body as a "temporal wrapping" for an "immortal soul" (similarly as in Plato's writings, see e.g. Plato, 1999) is common in Polish culture, which might be connected with the Catholic religion (which is influenced strongly by Platonism) as dominant in Poland.

3 The research participant is using a masculine form to describe the person in question, even though the character herself identifies as female. This may be due to a grammatical form used in the original story and the lack of a gender neutral form in Polish that has an equivalent to the English "they".

4 The interviewee talks about his childhood in the late 1970's and relates to the limited accessibility of other than Soviet Union propaganda literature for youths.
} 
the interview participants would believe in being supernaturally returned to the deserved corporeality they desired to have.

Of importance is that those childhood daydreams of magical metamorphosis seem to be framed within the "wrong body" discourse: recalling the plans of having their bodies altered as to be perceived as recognizable with their experienced gender, and linking the eligibility of one's gender identity with a social perception of one's body. People who shared these stories identified within the binary-gender framework, describing themselves not as gender queer or gender non-conforming but as trans men and trans women, often recalling the notion of transsexuality and the desire of transitioning since early childhood.

Yet, similar daydreams may also appear in adults. As Amy, an esoteric-oriented transwoman from the US says:

\begin{abstract}
" $<\ldots>$ I can tell you about my dreams as an adult when I finally started to come to terms with what was going on with me $\langle\ldots\rangle$ daydreaming of being a different gender from birth $\langle\ldots\rangle$ wishing for the magical pill to change if there was one. Would I take it? A bit hard to let go and not know what to expect but certainly would like to give it a try. Perhaps a relief of struggle and a fresh start in a place that was something that had been itching at me for a long, long, long, long time $\langle\ldots\rangle$. At the start I had no idea how far this would go. I saw others transitioning and it seemed so natural for some of them $\langle\ldots\rangle$ well maybe not for some, like they say, some are just doing what they wanted their whole lives. I have had resistance and doubt and tried to let myself grow into it and not rush $\langle\ldots\rangle$ but If I had a magical pill that would be so much easier to change genders because then I could pick and choose what to look like $\langle\ldots\rangle$ well maybe I can and maybe I can't $\langle\ldots\rangle$ would that be a chance to take? I felt the desire to express myself and wishing that I look a certain way, some way that seemed more in line with the average and probably even more than the average. Possibly swayed by advertising and/or a society tells us we need to be" (Amy, US).
\end{abstract}

Since epic stories might have evolved from, and are related to, symbolic mythologies (Mieletinski, 1981, pp. 324-332, also see Eliade, 1968), it is not surprising that some components of mythical thinking are also visible in the stories recalled by the interview participants: dialectic thinking, based on oppositions and dychotomic structure (male/female, coherence/incoherence, etc.); understanding the world in categories of complementary contradictions (Lévi-Strauss, 1963, 1966); the emotional component of its' symbolic form, the lack of differentiation between empirical and spiritual contents (Cassirer, 1977, p. 174, also see Cassirer, 1955); insusceptibility to critic; the feeling of being cast in a random world and thus the need to control it in an imaginary way, by the reference to supernatural, mythical powers (Habermas, 1999, p. 54, 95-99).

\title{
3. Collective trans-mythologies
}

According to Bronisław Malinowski, myth is an intrinsic component of every culture (1990, p. 349). The language of mythologies seems to derive from measureless sources of experience and memory, an existence we are sometimes unaware of (Fromm, 1977, p. 26). As a cultural utility, myth helps us to manage the surrounding world and be ourselves in it (May, 1997, p. 27). According to Rollo May (similarly to Carl Gustav Jung and Erich Fromm), we cannot cease to distinguish the need of myth, as it is dormant in all of us, inherent to our humanity (May, 1997, p. 17; compare Jung, 1996; Fromm, 1977). 
As it may be concealed in our collective unconsciousness, myth contains the legacy common to all people (Jung, 2011) that expresses itself in symbolic forms through dreams, fantasies, art, mythical and epic stories, etc. A large part of our lives is spent immersed in our unconsciousness: for example, while sleeping or daydreaming. This is especially true in children (just like in case of the respondents whose stories were recalled above), as children start their lives in unconsciousness and gradually mature into the state of consciousness (Jung, 1987). Amy, who recalls similar daydreams from her adult life, declares her regaining the connection to the collective unconsciousness:

"Me, I was searching for myself all my life. Always felt there was something else $<\ldots>$
but what $<\ldots>$ I seemed to feel a disconnect from a lot of things in my teenage years
$<\ldots>$ and then bam an opening and change of conscience thought somehow man-
ifested $<\ldots>$ not directly related to gender but more on the morphogenetic field or
collective consciousness $\langle\ldots\rangle$ tried to live my life in that direction, doing better at
times and worse at others. Hoping, wishing for more and doing what I could to that
end" (Amy, US).

A particular attribute of unconsciousness is its compensatory actions. The unconscious responds to human experience and in a way that addresses the necessities and rules of an internal human life. This enables a human to adopt an attitude that is concordant with the entire psyche (Jacobi, 1993, p. 24). The content of the unconsciousness receives its value and place because of confrontation with the consciousness. While the consciousness is always inclined toward adjusting the self to the exterior world, the collective unconsciousness works to achieve its own goal, which is replenishment and wholeness of psyche (Jacobi, 1993, pp. 54-55). This similarly describes how the interviewees' daydreams were a compensation of what they felt they were missing in their lives and the exterior world.

Additionally, the collective unconsciousness contains elements comprising a stratification of typical (i.e. independent on historical, ethnical and other differences) properties of humanity since its primal reactions are to common, conjoined human situations (Jacobi, 1993, p. 24). Thus, these individual stories of a magical trans-formation seem to be reflective of transformative mythologies and fictional stories.

Two such exemplary stories - one mythical and the other popular fiction - exemplify the long-standing imaginative potential of crossing or transcending binary genders in the collective unconsciousness. The first is the Greek myth of Tiresias, the blind prophet of Apollo who, upon crushing the female half of a pair of copulating snakes, was transformed into a woman by the gods. Seven years later, while seeing another pair of copulating snakes in the exact same place, Tiresias crushed the male and thus was transformed into a man:

\footnotetext{
"Teiresias had seen two serpents in the act of coupling. When both attacked him, he struck at them with his staff, killing the female. Immediately he was turned into a woman, and became a celebrated harlot; but seven years later he happened to see the same sight again at the same spot, and this time regained his manhood by killing the male serpent" (Graves, 1955, par. 105.h).
}

Although the decision to undergo the sex and gender transformation does not emanate from the titular individual in question but rather is a choice made by unseen deities far removed from the protagonist's immanence, Tiresias gained a knowledge beyond the single- 
gendered individuals' experience: even Hera and Zeus would seek Tiresias's advice regarding genders' differing experience (Graves, 1955, par. 105.h).

The second story is Orlando: A Biography (originally published in 1928), Virginia Woolf's famous novel that describes not only the male-to-female magical transition of the protagonist but the gender shifts and ambivalences of them and other characters:

"<...> Orlando woke. He stretched himself. He rose. He stood upright in complete nakedness before us, and while the trumpets pealed Truth! Truth! Truth! We have no choice left but confess - he was a woman $\langle\ldots$. . Orlando stood stark naked. No human being, since the world began, has ever looked more ravishing. His form combined in one the strength of a man and a woman's grace $\langle\ldots\rangle$. Orlando looked himself up and down in a long looking-glass, without showing any signs of discomposure $\langle\ldots>$. Orlando had become a woman - there is no denying it. But in every other respect, Orlando remained precisely as he had been. The change of sex, though altered their future, did nothing whatever to alter their identity. Their faces remained, as their portraits prove, practically the same. His memory - but in future we must, for convention's sake say 'her' for 'his' and 'she' for 'he' - her memory then, went back through all the events of her past life without encountering any obstacle. Some slight haziness there may have been, as if a few dark drops had fallen into the clear pool of memory; certain things had become a little dimmed; but that was all. The change seemed to have been accomplished painlessly and completely and in such a way that Orlando herself showed no surprise at it $\langle\ldots\rangle$. Orlando was a man till the age of thirty; when he became a woman and has remained so ever since" (Woolf, 1973, pp. 92-93).

Just like Tiresias, Orlando also gains insight into experiences of a more comprehensive humanity by overcoming the seeming gender disjunctions: " $<\ldots>$ she was man; she was woman; she knew the secrets, shared the weaknesses of each. It was a most bewildering and whirligig state of mind to be in" (Woolf, 1973, pp. 106-108), "< ..> change was incessant, and change perhaps would never cease” (Woolf, 1973, pp. 119-120).

Both of these stories - separated by different generations and disparate cultures - reflect an acknowledgement of, if not the same longing for, moving between genders. As much as an intelligible man and woman were components of social structures, one may reason so were those who desired to transcend the recognizable binary framework of gender. Also, these incidences of gender transition are not neutral transitions, as both Tiresias and Orlando gain various social and spiritual insights because of their trans-formations: a wisdom, a gift of prophecy, etc. Moving between genders gifts them with keen understandings of human desires, natures and conditions.

\section{Where and when gifts are granted}

In individual transsexual narratives, gender transformation can be perceived as a Gennepian rite of passage (Bolin, 1988), a dramatic change of status via altered corporeality demarcated by a fixed starting and end point. The journey between these fixed points occurs in a space of liminality that allows the individual (or "threshold people/liminae personae" (Turner, 1969)) to be empowered with various perceptions enabling them to move onto their new status. Echoing the stories of Tiresias and Orlando, Victor Turner argues that with transformation comes a gaining of insight, a granting of wisdom that in fact allows continued movement to a higher stage (1969, pp. 363-364). 
The idea that those undergoing transition will receive particular insights and perceptions because of their changes lies at the theoretical center of the anthropological rites of passage (Gennep, 1960). Arnold van Gennep constructs change of (cultural) status as a tripartite ritual in which the initiate first must undertake a separation from their prior status, pass through a transitional (or liminal) phase, only to be then reinstated into society under the category of their new title (1960, pp. 10-11). Such conversion describes potential mobility within any class, from the remaking of an individual into a community/tribal leader, to a novice who moves from apprenticeship to mastery; or from a single individual who becomes a married spouse, to an adolescent who undergoes cultural or religious ceremonial to become considered a young adult.

So pivotal is the middle-bridge or transitional phase that Gennep re-signifies the separation and re-installation stages: pre-liminal and post-liminal, respectively (1960, p. 21). This stage holds the most potential for change since "[w] hoever passes from one to the other [status] finds himself physically and magico-religiously in a special situation for a certain length of time: he wavers between two worlds" (Gennep, 1960, p. 18). Without the comforts and safety of their prior identity, and still unbeknownst to their future incarnation, the individual finds themselves located in a state of unmarked potential.

In further examining the middle stage of rites-of-passage, Turner (1969) argues this liminal phase is not passive or static state but rather an intentional phase of informative and transformative dynamics. Transitioning "initiates", he argues, discover the separation process strips them of those social entitlements inherent in their former status, leaving them as erased personae, so much "tabula rasa, a blank slate, on which is inscribed the knowledge and wisdom of the group, in those respects that pertain to the new status" (Turner, 1969, p. 364). Made vulnerable, these "threshold people" or "liminal personae" would now be open to receiving "gifts" that will empower them upon the completion of their transition and re-stabilization of their identities. Turner is careful not to specify the form or content of these "gifts", implying they may be personalized for or by the individual. This dynamic suggests the initiate cannot receive insights while still clinging to the understandings of their prior status, and subsequently cannot move through the re-installation phase to embrace their new status without those wisdoms.

Both the Tiresias and Orlando storylines include these parting of "gifts". Some versions of the Greek mythical story have Tiresias - originally punished to be a woman after killing one of copulating snakes - learning their lesson after being in female form (the Lady Tiresias) for seven years. During this time period Tiresias becomes a high priestess of Hera and a renown courtesan, thereby learning the insights of both a male and a female. Orlando learns through their transition the temporality of desire, relationships and social norms, noting, "the true length of a person's life, whatever the 'Dictionary of National Biography' may say, is always a matter of dispute" (Woolf, 1973, p. 216).

A similar idea of overcoming a binary in a rite of passage, where the transformation is identified with perfection was expressed e.g. in the medieval alchemical philosophy (see Kłonkowska, 2010, 2014). The alchemists' maxim, according to Rosary of the Philosophers, was: Aurum nostrum non est aurum vulgi ["our gold is not a common gold"] ${ }^{5}$ (warburg.

\footnotetext{
5 Translated from Latin by one of the authors.
} 
sas.ac.uk, 2018, p. 220) - although they were occupied with the art of gold production, the chemical transformation seemed to interest them not for itself, but as a reflection of a psychological, identity-related process that had been projected on the process of transmutation of matter (Eliade, 1978; Jung, 1944). The symbolic stages of the alchemical process (see Read, 1997, pp. 130-148) were an allegorical representation of an adept in subsequent phases of "suffering", "death" and "resurrection" (separation, liminality and reinstatement) (Eliade, 1978, 11, 142-168), granting in the result a new integrity of a human being (Jung, 1944, p. 58). One of the central symbols of this trans-formation was lapis - the philosopher's stone symbolizing overcoming in opus magnum the binaries commonly perceived as oppositions. And a common representation of those binaries was the male - female dichotomy, in which the opus alchymicum was presented as masculine and feminine "natures converted" in a trans-mutation (trans-formation), as Nicolas Flamel claims in his 17th century publication:

"Then thou hast here two natures married together, whereof the one hath conceived by the other and by this conception it is turned into the body of the Male, and the Male into that of the Female <...>" (1995, p. 28).

The gifts granted to the adepts successfully going through this rite of passage were wisdom, enlightenment and the interior, psychological integration (Jung, 1944, p. 349): Ex aliis nunquam unum facies quod quaeris, nisi prius ex teipso fiat unum ["You cannot unite others which you seek - if you don't unite yourself first"] ${ }^{6}$ (digital.slub-dresden.de, 2018, p. 417).

\section{Trans-formative motives}

The question of why some transsexual identifying individuals search in their culture's collective folklore for articulation of their conditions may be answered in what that mythos offers. While many mythologies promote the gender binary by attributing various common gender markers to their gods and goddesses, many also offer in their narratives socially-acceptable transpositions, a breakdown - or at least a limited suspension - of the bipartite between men/ male and women/female gender (Kłonkowska, 2014). When enacted by the gods, or individuals participating in the domain of sacrum, the crossing of culturally recognized bipartite genders whether in clothing, actions or even bodies carry no threat of, and remains beyond social judgement, punishment, and stigma.

Such waivers were extended to their followers. During designated fetes and celebrations, social taboos were lowered for the duration of the fetes. It was not uncommon for men and women to adorn themselves in the clothing and other visible gender markers of the "opposite" gender (Kłonkowska, 2014, p. 122) ${ }^{7}$. It is critical to note that, similar to Turner's liminality located at the heart of Gennep's rites-of-passage, these parties celebrating cultural mythologies allow for a change (and challenge) of norms under a limited space and time that would otherwise not be accessible or acceptable.

Perhaps most potently than other gender-specific archetypes, the mythical androgynous (or hermaphrodite) figure is the most potent metaphor of an ancient longing to bridge the

\footnotetext{
6 Translated from Latin by one of the authors.

7 The celebration of Halloween in the US and other Western countries offers a modern day example.
} 
divide between male and female, to embrace in synthesis that sum of the parts greater than the whole. That desire seems deeply embedded in the collective conscious since

\begin{abstract}
" $<\ldots>$ in common notion, human beings - as imperfect creatures (unlike the beings participating in the reality of sacrum) - were condemned to being partied into those two opposed male-female categories, and allowed to experience just one of the aspects of being a human: either a man or a woman. This bipartition - for generations remaining inherent in our notion of the human reality - excluded the Androgyny and social construction of gender bipartition phenomenon of "anything between" and "anything two-fold" or "anything beyond", making us the "tally-halves of a human" (Kłonkowska, 2014, pp. 123-124).
\end{abstract}

Cultural mythologies both offer an articulated example of gender-crossing, both temporary and permanent, and androgyny and create a liminal immanent space for these otherwise forbidden acts to take place. And while the motives these stories promote for such transitions no longer resonate in modernity, they do supply reasons nonetheless, suggesting the causes for gender transition may ultimately reside outside of human comprehension.

\title{
Conclusions: the power of myth in the contemporary world
}

For some who identify as transsexuals, the use of mythology and folklore elements in their personal narratives offers various advantages: a powerful and creative articulation of internal desires, imperatives, and identities that more formalized language has yet to fully develop (science) or accurately reflect (academia); the festive space to experiment beyond those regulated gender norms that act as social controls; the gift of insights imparted by journeying through liminal phases; and perhaps to have the burden of choice and the responsibilities of subsequent outcomes removed in favor of divine, magical or otherwise otherworldly intervention. While the power of myth may reside solely in the imaginative and manifest only as dreams and unsatisfied wish-fulfilments, it remains (much as it ever has) an option that does not require health insurance waivers and institutional gatekeepers.

If power is destined to give birth to its own resistance (Foucault, 1990, p. 96) then it should come to no surprise to find that within binary frameworks there exists, and always has, the desire, imperative and acknowledgement of movement crossing over supposedly foundational gender taxonomies, on sociopolitical and collective mythological levels. These two levels productively intersect in the transsexual standpoint where, embedded in personal narratives, threads of magical trans-formations speak to the existence of this juncture. From this intersection of the mythical and the personal emerge a number of potent properties worth further exploration. For example, as both fiction and theories suggest, there is an embedded wisdom within the liminal of trans-formations that could not be gleaned otherwise.

That such empowerments exist only as effects of the liminal call into question the supposed long-standing immobility of gender identities, for it implies that of a fecundity of the threshold that cannot be obtained by remaining safely ensconced in singular gender-specificity. As noted in Greek mythology, the gift of prophecy (even as an effective of punishment) could not have been afford Tiresias without first transgressing the binary. Likewise, Orlando would not have gathered amongst them the wisdom they collected had they remained male- 
bodied. Their phenomenological gleanings - much like those found in various transsexual/ transgender/queer memoirs and fictions such as Gender Outlaws: The Next Generation (Bornstein \& Bergman, 2010), Redefining Realness: My Path to Womanhood, Identity, Love \& So Much (Mock, 2014) and Stone Butch Blues (Feinberg, 2010) - considered invaluable by those who receive them, simply could not have even be gifted without a trans-formation first.

The desire for magical-transformations found within transsexual narrative also speak to an established desire located squarely within the binary. It is unclear though if removing the binary would subsequently release this desire in productive ways. There is a class of feminists - such as self-identified radical feminists (or trans-exclusionary "radfems" (colloquially, trans-exclusionary radical feminists)) - among others - who argue that transsexuality/ transgender is merely the effect of gender classification itself; therefore, taking a Marxist stance, to move toward a post-gender would be to dissolve the gender classes and any need to transgress them. The two are seemingly related and even intertwined (at least on a theoretical level) that, for instance, noted anti-trans theorist Sheila Jeffreys argues:

"(i)n the practice of transgenderism, traditional gender is seen to lose its sense of direction and end up in the minds and bodies of persons with inappropriate body parts that need to be corrected. But without gender, transgenderism could not exist $\langle\ldots\rangle$ [transgender] gives authority to outdated notions of essentialist differences between the sexes" (2014, p. 2).

Here the transgender experience is solely constructed as a particular and particularizing class effect of an oppressive binary-gendered system. So intimately connected are they that the removal of the latter (cited by Jeffreys as a core feminist goal) will be the dismissal of the other. This remains theoretical, of course as Judith Butler (1990, pp. 23-24) suggests that although we can be able to live outside a gender binary - existing outside of any gender completely may not be a tenable goal (compare Salih, 2002).

\section{Funding}

This work was supported by the Fulbright Program under Senior Research Fellowship Award received by Anna Maria Kłonkowska in academic year 2016/2017.

\section{References}

Benjamin, H. (1966). The transsexual phenomenon. New York: The Julian Press, Inc. Publishers.

Bettelheim, B. (2010). The uses of enchantment: The meaning and importance of fairy tales. New York: Vintage Books.

Bolin, A. (1988). In search of Eve: transsexual rites of passage. New York, NY: Bergin \& Garvey Publishers, Inc.

Bornstein, K., \& Bergman, S. B. (2010). Gender outlaws: The next generation. Berkeley, CA: Seal Press.

Butler, J. (1990). Gender trouble: feminism and the subversion of identity. Series: Thinking Gender. Nicholson, L. J. (Ed.). New York, London: Routledge.

Cassirer, E. (1977). Esej o człowieku: Wstęp do filozofii kultury. Series: Nowy Sympozjon. Warszawa: Czytelnik. 
Cassirer, E. (1955). The philosophy of symbolic forms. Vol. 2: Mythical Thought. Yale: Yale University Press.

Charmaz, K. (2006). Constructing grounded theory: A practical guide through qualitative analysis. London: SAGE Publications Ltd.

digital.slub-dresden.de. (2018). Theatrum chemicum, praecipuos selectorum auctorum tractatus de chemiae et lapidis philosophici antiquitate, veritate, iure, praestantia, \& operationibus continens. $B d .1$. Retrieved from http://digital.slub-dresden.de/werkansicht/dlf/23652/1/0/

Eliade, M. (1968). Myth and reality. New York: Harper \& Row.

Eliade, M. (1978). The Forge and the Crucible: The origins and structures of alchemy. Chicago and London: Phoenix Edition.

Feinberg, L. (2010). Stone butch blues: A novel. New York: Alyson Books.

Flamel, N. (1995). Hieroglyphical figures: concerning both the theory and practice of the philosophers stone (1624). Whitefish, MT: Kessinger Publishing.

Forrest Miller, J. (2017). I wanna know where the rule book is: YouTube as a Site of Counternarratives to Transnormativity (Master Thesis). Atlanta: Georgia State University (unpublished source). Retrieved from https://scholarworks.gsu.edu/cgi/viewcontent.cgi?article=1063\&context=wsi_theses

Foucault, M. (1990). The history of sexuality. Vol. 1: An Introduction. New York: Vintage Books.

Fromm, E. (1977). Zapomniany język. Wstęp do rozumienia snów, baśni i mitów. Warszawa: PIW.

Gennep, van A. (1960). The rites of passage. Chicago, IL: University of Chicago Press.

Graves, R. (1955). The Greek myths. Vol. 2. New York, NY: Pelican Books.

Habermas, J. (1999). Teoria działania komunikacyjnego. Vol. 1. Series: Biblioteka Współczesnych Filozofów. Warszawa: Wydawnictwo Naukowe PWN.

Hines, S. (2007). TransForming gender: Transgender practices of identity, intimacy and care. Bristol: The Policy Press (University of Bristol). https://doi.org/10.2307/j.ctt9qgpqw

Jacobi, J. (1993). Psychologia C. G. Junga. Przedmowa Carl Gustav Jung: Wprowadzenie do całości dzieła. Warszawa: Wydawnictwo Wodnika.

Jeffreys, Sh. (2014). Gender hurts: A feminist analysis of the politics of transgenderism. New York, NY: Routledge. https://doi.org/10.4324/9781315778266

Jung, C. G. (1996). C. G. Jung Gesammelte Werke. Bd. 9/1: Die Archetypen und das kollektive Unbewußte - Aus Gesammelte Werke 1-20 neunter Band, erster Halbband. Zürich, Düsseldorf: WalterVerlag.

Jung, C. G. (2011). C. G. Jung Gesammelte Werke. Bd. 6: Psychologische Typen. M. Niehus-Jung, L. Hurwitz-Eisner, F. Riklin, \& L. Zander (Hrsg.). Ostfildern: Patmos Verlag der Schwabenverlag AG.

Jung, C. G. (1987). C. G. Jung Gesammelte Werke. Suppl. Bd.: Seminare: Kinderträume. Jung, L, \& Meyer-Grass, M. (Hrsg.). Olten und Freiburg: Walter.

Jung, C. G. (1944). Psychologie und alchemie. Zürich: Rascher Verlag.

Kłonkowska, A. M. (2010). Alchemical theory and practice as overcoming the split between the domain of culture and life itself. Miscellanea Anthropologica et Sociologica, 10/11, 171-183.

Kłonkowska, A. M. (2014). Dual-unity or dichotomy? Androgyny and social construction of gender bipartition. Creativity Studies, 7(2), 118-134. https://doi.org/10.3846/23450479.2014.944595

Kłonkowska, A. M. (2017). Płeć: dana czy zadana? Strategie negocjacji (nie)tożsamości transpłciowej w Polsce. Gdańsk: Wydawnictwo Uniwersytetu Gdańskiego.

Leyen, von der F. (1973). Mit i baśń. Pamiętnik Literacki: czasopismo kwartalne poświęcone historii i krytyce literatury polskiej, 64(1), 293-309.

Lévi-Strauss, C. (1966). The savage mind. Series: The Nature of Human Society Series. Chicago: The University of Chicago Press. 
Lévi-Strauss, C. (1963). Totemism. Boston: Beacon Press.

Lüthi, M. (1973). Style gatunkowe. Pamiętnik Literacki: czasopismo kwartalne poświęcone historii i krytyce literatury polskiej, 64(1), 283-292.

Malinowski, B. (1990). Mit, magia, religia. Series: Dzieła. Vol. 7. Warszawa: PWN.

May, R. (1997). Błaganie o mit. Poznań: Zysk i S-ka Wydawnictwo.

Meyerowitz, J. (2004). How sex changed: A history of transsexuality in the United States. Harvard: Harvard University Press.

Mieletinski, E. (1981). Poetyka Mitu. Warszawa: PIW.

Mock, J. (2014). Redefining realness: My path to womanhood, identity, love \& so much more. New York, NY: Atria Paperback.

Plato. (1999). Phaedo. Series: Oxford World’s Classics. Oxford: Oxford University Press.

Propp, W. (2000). Nie tylko bajka. Warszawa: Wydawnictwo Naukowe PWN.

Read, J. (1997). Prelude to chemistry: An outline of alchemy, its literature and relationships. Whitefish, MT: Kessinger Publishing.

Salih, S. (2002). Judith Butler. Series: Routledge Critical Thinkers. R. Eagleston (Series Ed.). London and New York: Routledge. https://doi.org/10.4324/9780203118641

Spade, D. (2000). Mutilating gender. Retrieved from http://www.makezine.org/mutilate.html

Stone, S. (1991). The "empire" strikes back: A posttranssexual manifesto. In J. Epstein \& K. Straub (Eds.), Body guards: the cultural politics of gender ambiguity (pp. 280-304). New York: Routledge.

Tolkien, J. R. R. (2001). Tree and leaf. London: Harper Collins Publishers.

Turner, V. (1969). Liminality and Communitas. In V. Turner, The ritual process: Structure and antistructure (pp. 358-374). New Brunswick and London: Aldine Transaction.

Vincent, B. W. (2016). Non-binary gender identity negotiations: Interactions with queer communities and medical practice (Doctoral Thesis). Leads: The University of Leeds (unpublished source). Retrieved from http://etheses.whiterose.ac.uk/15956/1/Vincent_BW_Sociology_PhD_2016.pdf

warburg.sas.ac.uk. (2018). Artis Avriferae, Qvam Chemiam Vocant. Vol. 2: Qvod continet Morieni Romani scripta de re metallica atque de occulta summaque antiquorum medicina. Retrieved from https://warburg.sas.ac.uk/pdf/fgh100b3193420B.pdf

Woolf, V. (1973). Orlando: A biography. New York: Harcourt Brace Jovanovich.

\title{
ASMENINĖS IR KOLEKTYVINĖS TRANSMITOLOGIJOS: KÜRYBINIAI POŽIŪRIAI ț LYTIES NEATITIKIMĄ TARP TRANSLYČIŲ ASMENŲ
}

\author{
Anna Maria KŁONKOWSKA, Stephanie BONVISSUTO
}

\begin{abstract}
Santrauka
Naratyviniai elementai, vis dažniau aptinkami kultūriniu požiūriu specifinių legendų steigiamame fone ir sąveikaujant mitologinèms figūroms, yra ịtraukti ị kai kurių translyčių žmonių biografijas. Asmenys, kurie specifiniu būdu identifikuoja save kaip transseksualus (skirtingai nei kiti transseksualūs asmenys - nebinarinès lyties ar lytiniai keistuoliai), kartas nuo karto praneša apie norą, svajonę ir / ar troškimą suprasti ar sušvelninti jų patiriamą lytinị neatitikimą stebètinai kūrybišku būdu stebuklinga tam tikro pobūdžio transformacija. Remiantis neseniai surinktais interviu, šiame tyrime nagrinejjami tie naratyvai ir jų elementų naudojimas, atkreipiant
\end{abstract}


dėmesį $\mathfrak{x}$ jų priklausomybę nuo binarinių lyties struktūrų. Pasitelkiant filosofinius ir kultūrinius-antropologinius tyrimus, teigiama, kad šios sritys teikia paveikių ir kūrybiškų asmeninių išlygų, galimybių ir suvokimų individų, save identifikuojančių kaip translyčius, atžvilgiu: stebuklingos transformacijos ir pagrịsti perkèlimai, siekiant sušvelninti disforiją, asmens atsakomybès kapituliavimą universalių dvasinių jègų akivaizdoje ir ypač prigimtinę išmintị, suteiktą pereinamojo liminalumo, o to neteikia nei moksliniai, nei akademiniai lyties keitimo vertinimai. Nors šios kūrybinès išlygos yra pramanytos, neittikimos ir laikinos, vis dèlto jos artikuliuoja supratimo, išraiškos ir galiausiai jei ne imperatyvo, tai bent veiksmo pereinančiojo asmens atžvilgiu poreikị.

Reikšminiai žodžiai: kūrybinis požiūris, lyties neatitikimas, stebuklinga transformacija, perejimo ritualas, translyčiai asmenys, transseksualūs asmenys, „netinkamo kūno" diskursas. 